\title{
RELATIONSHIP BETWEEN INSECT DAMAGE AND CHLOROPHYLL CONTENT IN MEDITERRANEAN OAK SPECIES
}

\author{
CÁRDENAS, A. M. ${ }^{*}-$ GALLARDO, P. \\ Dpto. de Zoología, Edificio Darwin, Campus Rabanales, E-14071, \\ University of Córdoba, Córdoba, Spain \\ (tel: +34957218604$)$ \\ *Corresponding author \\ e-mail:balcataa@uco.es \\ (Received 10 $0^{\text {th }}$ Jun 2016; accepted 23 $3^{\text {rd }}$ Jul 2016)
}

\begin{abstract}
Considering that the damage caused by phytophagous insects can alter the chlorophyll content of plants, we established the hypothesis that variations in chlorophyll concentration could be applied to assess stress caused by these kind of harmful agents. In this paper, relationship between insect damage and the chlorophyll content of sclerophyllous oak species (Quercus suber and $Q$. ilex) is investigated. The survey was carried out in Hornachuelos Natural Park (southern Iberian Peninsula). For each plant species, a comparative study of chlorophyll concentration on healthy leaves was performed among a control group of harmless trees and other groups affected by one of the following damaging insects: woodborers, chewing and gall-formers. Results relative to $Q$. ilex indicated that only damage by gall-formers had a significant effect on average chlorophyll content of healthy leaves. As regard $Q$. suber, differences in chlorophyll content were only significant when injuries were caused by the woodborer Coraebus florentinus. In conclusion, insect damage could influence the chlorophyll content of the holm and cork oaks, but the effect varies depending on the plant species and the type of harmful agent.
\end{abstract}

Keywords: environmental assessment, oak forests, Quercus ilex, Quercus suber, photosynthesis

\section{Introduction}

Several herbivorous insects are associated with Quercus species (Romanyk and Cadahía, 1992) and, depending on the way of affecting the plant, can be classified as woodborers, carpophagous and folivorous (chewing insects and galls-formers). The most prevalent woodborers in oak forests in southwest Spain are the longicorn's species belonging to the Cerambyx genus (Coleoptera: Cerambycidae) and the jewel beetle Coraebus florentinus (Herbst, 1801) (Coleoptera: Buprestidae) (Montoya, 1989). The larvae of these xylophages drill trunks and branches and cause considerable damages and even tree death. Other insects feed on Quercus leaves: i.e. larvae of Lymantriidae, Tortricidae, Noctuidae (Lepidoptera) and Curculionidae or Chrysomelidae (Coleoptera). These chewing insects eat leaves, flowers, buds and twigs. They can seriously damage foliage, reducing plant fitness (Hochwender et al., 2003) and regenerative capacity (Howe, 1990), and also affecting photosynthesis and plant growth (Doyle et al., 2002). In addition, some Diptera and Hymenoptera can also affect leaves producing galls.

Plants develop several compensatory mechanisms to these damages by increasing their relative grow rate, activating the growth of meristems or enhancing photosynthetic activity (Mizumachi et al., 2006). As regards photosynthesis, the effects of phytophagous can be understood in two ways: direct effects if they remove photosynthetic tissue (leaves); and indirect effects, if photosynthetic activity increases or decreases in tissues not directly damaged (Welter, 1989; Aldea et al., 2005). Relationship between 
photosynthetic activity and chlorophyll (Chl in advance) content in some Quercus species has been investigated in previous research (Gratani et al., 1998).

In another context, nowadays great importance is attributed to the evaluation of the condition of forests in order to identify states of stress induced by environmental changes (Bussotti, 1994). Assessment and monitoring of forest health represents a key point for environmental policy. Considerable work has already been done in monitoring the condition of forest trees, and there is an entire range of methods and diagnostic techniques. Nevertheless, these indicators are often difficult to incorporate into monitoring programs since they are time consuming and require adequate expertise. Therefore, it is necessary to develop reliable and consistent tools to assess health of forests.

Taking into account the possible effect of insect's damage on photosynthetic activity and the relationship between Chl content and photosynthetic rate (Šesták, 1966; Palta, 1990; Nagaraj et al., 2002; Zarco-Tejada et al., 2002), we formulated the hypothesis that Chl content may be a suitable tool for evaluating biotic stress caused by harmful insects. To validate this statement we explored if there is relationship between insect damage and Chl content of the major Mediterranean Quercus species. For that, we compared the $\mathrm{Chl}$ content of uninjured leaves of a control group of undamaged trees (without visible signs of damage by phytophagous insects) with those of other groups exclusively damaged by one of the following agents: woodborers, chewing insects or gall-formers.

This study is a part of a Research Project aimed to assess the incidence of harmful insects in the Quercus forest in the Hornachuelos Natural Park (southern Iberian Peninsula). This area is currently participating in an Environmental Recovery program (Cárdenas et al., 2008). Useful tools are needed to assess the long-term effectiveness of measures implemented. This research aimed to validate whether $\mathrm{Chl}$ concentration could be a simple but suitable index for assessing biotic stress caused by phytophagous insects in the main Quercus species from the Mediterranean forest, in the southern Iberian Peninsula.

\section{Review of Literature}

In literature, information is available regarding the effect of biotic agents such as herbivorous insect (Romanyk and Cadahia, 1992), other arthropods (Longonje et al., 2014), and pathogens on plants or on their photosynthesis rate (Osmond et al., 1990; Faeth, 1992; Jiao et al., 1999) and plant growth (El Omari et al., 2001). Alteration in phyto-chemistry of plants under environmental factors is well documented (Hunter, 2001; Khadar et al., 2014) and some studies have reported the effects of biotic damage on leaf and response in photosynthesis (Aldea et al., 2006; Tang et al., 2006). In addition, Aldea et al. (2006) stated that arthropods and pathogens damaging leaves in natural ecosystems may reduce photosynthesis rather than directly injured plant tissue, since foliar damage often triggers complex interactions between defensive processes and photosynthesis. Herbivory damage can alter plant physiology by inducing the production of costly defensive compounds or disrupting water and nutrient movements. These authors also found significant effects of fungal and galls infections on photosynthetic efficiency, while chewing damage (caterpillar damage) resulted in minor effects. Plants react against the effect of these harmful agents by developing compensatory mechanisms as activating the growth of meristems or enhancing photosynthetic activity (Mizumachi et al., 2006). Previous studies also indicate that, for 
some vegetal species, leaf Chl concentrations respond to pest presence (Baldy et al., $1996 \mathrm{a}$ and $\mathrm{b})$.

On the other hand, most existing assessments of forest condition are limited to ground-based visual evaluation (Zarco-Tejada et al., 2002). Although this procedure may be useful for other purposes, it is not practical for detecting physiological changes that characterize stress responses (Sampson et al., 2000). Nevertheless, the physiological evaluation of tree can indicate adaptability to environmental stress (Colombo and Parker, 1999) and may provide early signs of declines in stand vigour and health. Literature contains studies on the eco-physiological responses of plants in Mediterranean ecosystems that emphasize the relationships between photosynthesis and the multiple stress-factors characteristic of these environments (Marino, 2000). Chlorophyll fluorescence has been applied to assess environmental stress produced by abiotic factors in urban trees (Percival, 2005) and also in wild trees as Q. ilex L. 1753, (Bussotti, 1994). Percival (2004) found that Chl fluorescence was highly correlated to foliar damage in $Q$. ilex.

Research on the relationships between photosynthetic activity and Chl content in Quercus species revealed positive, but no significant, correlation between both parameters (Gratani et al., 1998). This is because other factors such as leaf age, nutritional status and a range of environmental and phenological conditions may also influence the relationship between photosynthetic rate and Chl content (Nagaraj et al., 2002; Barry et al., 2009). In addition, previous studies also indicate that leaf $\mathrm{Chl}$ concentrations respond to pest presence, among others agents (Baldy et al., $1996 \mathrm{a}$ and b).

\section{Materials and methods}

\section{Study area}

The study was carried out in the surrounding of the "Sierra de Hornachuelos" Natural Park, located in centre-western of the province of Córdoba (Andalusia, Spain; Figure 1). The main landscape is dominated by the Mediterranean oak forest. Vegetation in the area belongs to the Duriilignosa formation, represented by the Quercetea ilicis Type (Rivas-Martínez, 1974). It is constituted by perennial leaf and phanerophyte communities dominated by shrubs and bushes. The most representative species are: $Q$. ilex subsp. ballota (Desf.) Samp. (1908-9), Q. suber L. 1753, Pistacia lentiscus L.1753, Asparagus albus L. 1753 and different species of Erica and Cistus.

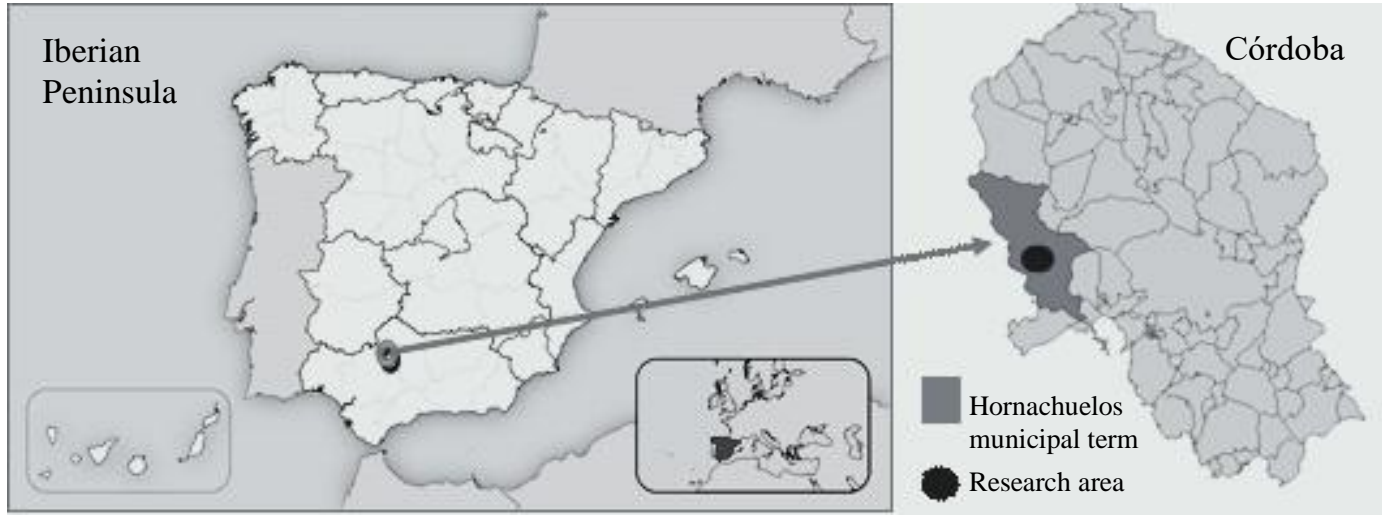

Figure 1. Location of the research area 
The climate in the area is typically Mediterranean, with annual rain-fall ranging between 500 and $800 \mathrm{~mm}$ and mean annual temperatures of $\approx 17^{\circ} \mathrm{C}$ (Figure 2). The summers are relatively warm (mean $\approx 24^{\circ} \mathrm{C}$ ), and the winters are temperate, with mean temperatures ranging between 6 and $10^{\circ} \mathrm{C}$ (Gallardo et al., 2010).

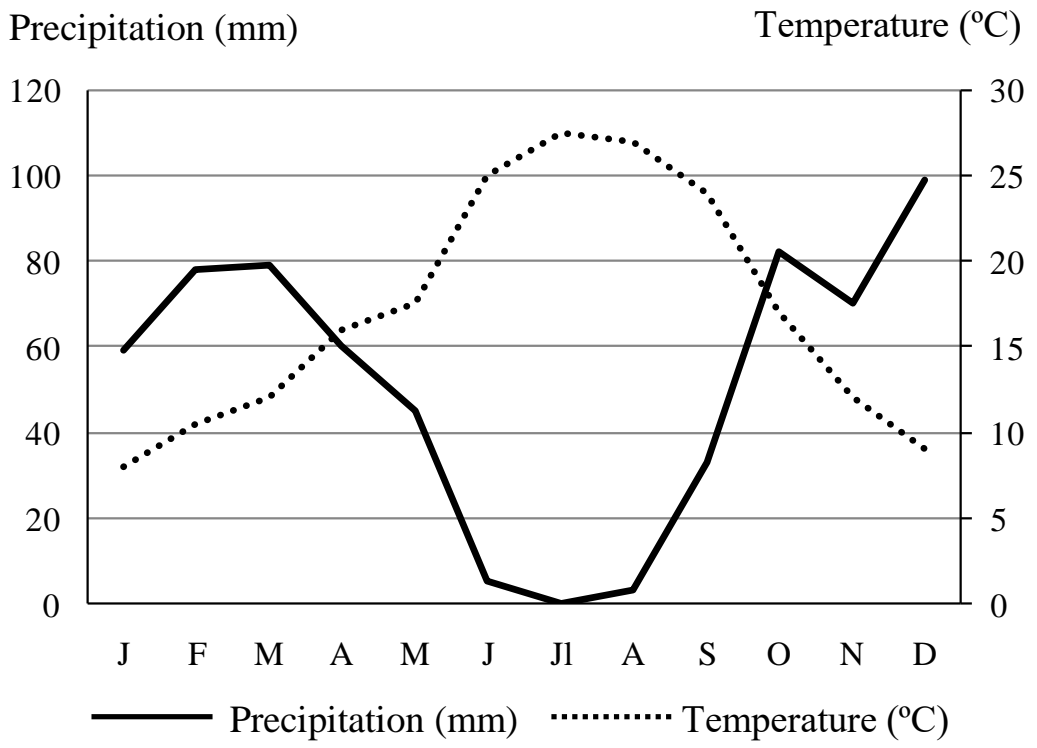

Figure 2. Climate-diagram with data from the Hornachuelos Meteorological Station (http://www.juntadeandalucia.es/agriculturaypesca/ifapa/ria/servlet)

\section{Damage assessment}

To assess damage, a total of 550 trees, including healthy and damaged trees, were thoroughly prospected. Sampling was carried out from March 2012 to September 2013. Damage caused by the Cerambyx group species (Figure 3) was searched during the entire sampling period by the identification and quantification of holes, after carefully prospecting around the trunk and the main branches in top of trees. Damage by $C$. florentinus was quantified counting the yellowish-brown dry branches on each examined oak (Figure 4).

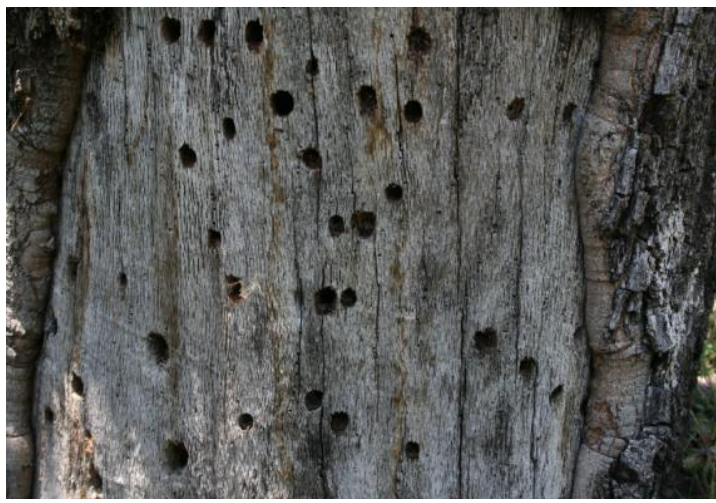

Figure 3. Damage in trunk of $\mathrm{Q}$. suber caused by the Cerambyx group species

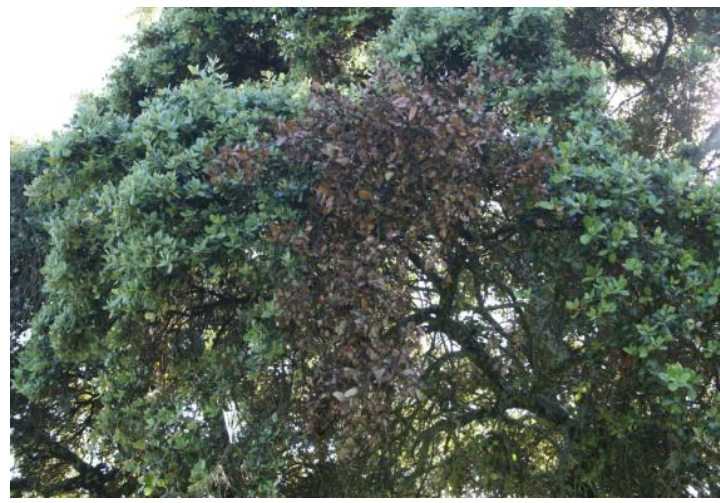

Figure 4. Damage in holm oak canopy caused by $\mathrm{C}$. florentinus 
Each sampling year, leaf damage caused by folivorous insects was sampled in spring (April-May), just after the trees had sprouted. Damage was estimated by visual inspection (using binoculars) of the canopy. This is the most commonly applied method in such surveys (Abbott et al., 1993; Mizumachi et al., 2006; Gu et al., 2008), provided the observers are sufficiently trained. After each top tree observation, a categorical scale with five levels according to the percentage of damaged leaves was applied (Johnson et al., 2001).

Damage caused by leaf-eating insects was typified as bites (free and hole feeding); skeletonising and galls (Coulson and Witter, 1984), (Figures 5, 6 and 7, respectively).

As the tree age could be an additional factor affecting the leaf Chl content, the age of each sampled oak was indirectly estimated measuring the trunk perimeter (recorded at breast height: 1,30 m; Orozco, 1982).

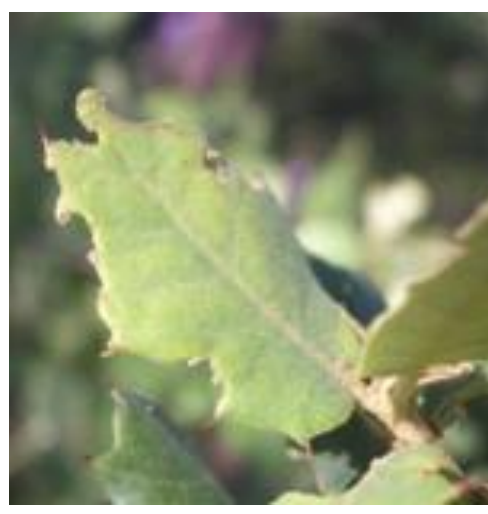

Figure 5. Bites in Q. ilex leaves

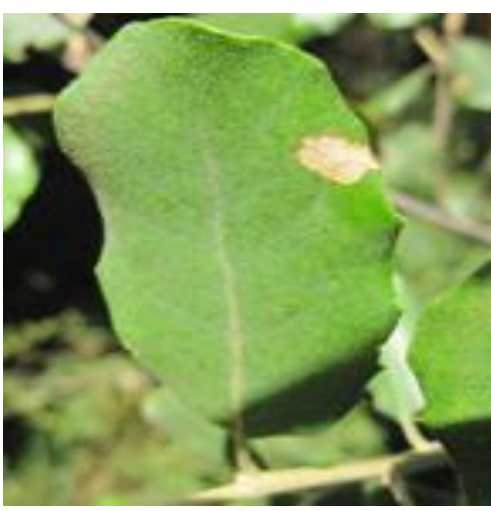

Figure 6. Skeletonising in $\mathrm{Q}$. ilex leaves

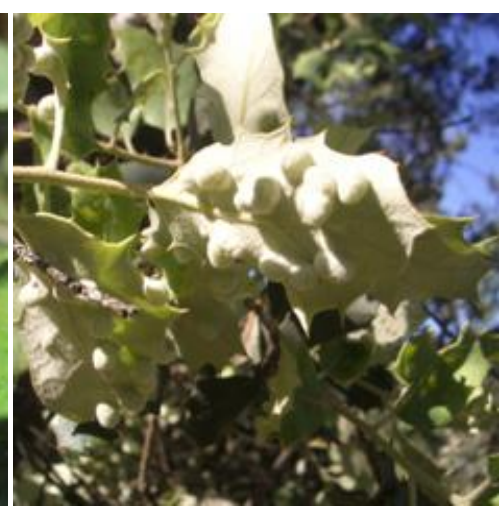

Figure 7. Galls in Q. ilex leaves

\section{Chlorophyll measurement}

Considering that $\mathrm{Chl}$ concentration on leaves strongly increases at the beginning of the growing season (from April to May; Demarez et al., 1999) and that the pattern of leaf senescence may also affect the Chl content (Gratani and Moriconi, 1989; Gratani and Bombelli, 2001), all the leaves were collected in winter (November-January), when the tree growth was minimal and the Chl content remains more stable (Oliveira et al., 1994; Castro-Díez and Montserrat-Martí, 1998).

For Chl extraction, a sample of 42 healthy trees ( 32 Q. ilex and 10 Q. suber) and 74 damaged trees ( $41 Q$. ilex and $33 Q$. suber) was considered. The damaged trees selected were those that showed exclusively damage caused by one of the harmful agent. A tree was considered healthy if it was free of woodborer damage and when the presence of folivorous insects did not surpass the first level ( see previous section). This was because it was assumed that, in nature, a variable proportion of leaves are always affected by phytophagous agents but at the lowest level this infestation does no cause stress or alters tree physiology (Domínguez and Tejero, 1972). In addition, to avoid the effect of differences in sun exposure from each analyzed tree a total of 10 leaves were collected at each orientation (N, S, E and W). Healthy and totally developed leaves were always selected for Chl extraction, even when they came from damaged trees.

Chl was extracted following the method proposed by Rodríguez de Cianzio et al. (1979) because this procedure extracts most (approximately 90\%) of Chl. In addition, the anatomical features (thickness, sclerophyllouse) of $Q$. ilex and $Q$. suber leaves 
(Andicoberry et al., 2007) would make data obtained from other easier procedures unreliable (for a fully description of Chl extraction methods see Palta, 1990).

$\mathrm{Chl}$ concentration was estimated as $\mathrm{mg} / \mathrm{g}$ of fresh weight, and was calculated from absorbance values to 644 and $663 \mathrm{~nm}$, applying the Lichtenthaler and Wellburn (1983) expression (Eq. 1):

$\left[2.02 *\right.$ Absorvance $_{644}+8.02 *$ Absorvance $\left._{663}\right] *$ Volume of methanol/ fresh weight of leaf strip

Chl content was expressed on a fresh weight basis rather unit area of leaf blade because this parameter is most reliable to relate photosynthetic rate and Chl concentration for thick leaves (Šesták, 1966), as are those from holm and cork oaks.

\section{Statistical analyses}

To rule out the possibility that $\mathrm{Chl}$ content could be affected by the tree age (indirectly estimated by the tree size), the Spearman correlation coefficient between trunk perimeter and Chl concentration was calculated. The T-test was used to check differences in Chl content between damaged and unharmed trees. The Shapiro-Wilk test was used to test normality of the distributions. When normality assumptions were not satisfied for any one or both of the groups, the equivalent non-parametric U Mann-Whitney test was applied. Analyses of variance homogeny and normality were achieved to satisfy the terms of parametric analysis (Zar, 1984). Data were statistically analysed using the SPSS statistical software (SPSS Inc. 20.0, 2011) with $\alpha$ value of 0.05 .

\section{Results}

\section{Preliminary analysis}

Table 1 shows the results of the average Chl content for healthy trees as well as for the trees affected by each of the harmful agents considered on this study. Data from each Quercus species were analysed independently. The correlation coefficient between the perimeter of the unharmed trees and their respective Chl content revealed no significant differences between the two considered parameters for any of the studied species: $Q$. ilex $\mathrm{r}=0.137, \mathrm{P}=0.228 ; Q$. suber $\mathrm{r}=0.103, \mathrm{P}=0.388$ ( $\mathrm{r}$ : correlation coefficient, $\mathrm{P}$ : signification).

Table 1. Mean Chl content $(\mathrm{mg} / \mathrm{g})$ of healthy trees and trees only affected by one of the harmful agents analysed. N: trees number; SE: standard error

\begin{tabular}{|c|c|c|c|c|c|c|c|}
\hline & & \multicolumn{6}{|c|}{ Chl Content } \\
\hline & & \multicolumn{3}{|c|}{ Quercus ilex } & \multicolumn{3}{|c|}{ Quercus suber } \\
\hline & & $\mathbf{N}$ & Mean Chl & SE & $\mathbf{N}$ & Mean Chl & SE \\
\hline & Healthy trees & 32 & 1.65 & 0.10 & 10 & 1.82 & 0.13 \\
\hline \multirow{5}{*}{ 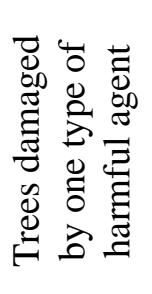 } & C. florentinus & 11 & 1.69 & 0.18 & 3 & 3.04 & 0.10 \\
\hline & Cerambyx sp. & 10 & 1.99 & 0.10 & 5 & 1.82 & 0.18 \\
\hline & Bites & 4 & 1.67 & 0.15 & 10 & 2.05 & 0.18 \\
\hline & Skeletonising & 1 & 0.98 & - & 10 & 1.77 & 0.21 \\
\hline & Galls & 15 & 2.02 & 0.10 & 5 & 2.05 & 0.28 \\
\hline
\end{tabular}




\section{Relationships between damage by borer-insects and chlorophyll content}

Table 2 shows the results of the tests performed to compare Chl content between healthy trees and those affected by a particular type of damage.

Table 2. Results of test performed to compare Chl content between healthy trees and those affected by a particular type of damage. P: significance; $N$ : trees number; $T$ : values of independent T test; Z: values of non-parametric U Mann-Whitney test. (*) statistical signification

\begin{tabular}{|c|c|c|c|}
\hline \multicolumn{4}{|c|}{ Statistics for mean comparison } \\
\hline Quercus ilex & $\mathbf{P}$ & $\mathbf{T} / \mathbf{Z}$ & $\mathbf{N}$ \\
\hline Healthy & \multirow{2}{*}{0.867} & \multirow{2}{*}{$Z=-0.167$} & 32 \\
\hline Damaged by $C$. florentinus & & & 11 \\
\hline Healthy & \multirow{2}{*}{0.098} & \multirow{2}{*}{$Z=-1.654$} & 32 \\
\hline Damaged by Cerambyx sp. & & & 10 \\
\hline Healthy & \multirow{2}{*}{0.919} & \multirow{2}{*}{$\mathrm{T}=-0.107$} & 32 \\
\hline Damaged by bite & & & 4 \\
\hline Healthy & \multirow{2}{*}{$0.011^{*}$} & \multirow{2}{*}{$\mathrm{T}=-2.684$} & 32 \\
\hline Damaged by galls & & & 15 \\
\hline Quercus suber & $\mathbf{P}$ & $\mathbf{T}$ & $\mathbf{N}$ \\
\hline Healthy & \multirow{2}{*}{$0.001^{*}$} & \multirow{2}{*}{-4.710} & 10 \\
\hline Damaged by $C$. florentinus & & & 3 \\
\hline Healthy & \multirow{2}{*}{0.982} & \multirow{2}{*}{0.023} & 10 \\
\hline Damaged by Cerambyx sp. & & & 5 \\
\hline Healthy & \multirow{2}{*}{0.333} & \multirow{2}{*}{-0.994} & 10 \\
\hline Damaged by bites & & & 10 \\
\hline Healthy & \multirow{2}{*}{0.842} & \multirow{2}{*}{0.202} & 10 \\
\hline Damaged by skeletonising & & & 10 \\
\hline Healthy & \multirow{2}{*}{0.426} & \multirow{2}{*}{-0.821} & 10 \\
\hline Damaged by galls & & & 5 \\
\hline
\end{tabular}

Considering first the species $Q$. ilex, and comparing the unharmed holm oaks $v s$. damaged trees by $C$. florentinus, the $\mathrm{Z}$ statistics did not reveal significant differences in Chl content between these two groups of trees $(\mathrm{P}=0.867)$.

Respect to relationship between damage by Cerambyx species, the results neither found significant differences in Chl content between undamaged trees and those showing hole lesions in trunk $(\mathrm{P}=0.098)$. Nevertheless, the additional information supplied comparing the data sets (box plots in Figures 8 and 9) shows different trends in response to damage caused by wood borer species: The Chl concentration in holm oaks damaged by Cerambyx species is slightly upper than when damage was due to the branch borer C. florentinus. The holm oaks in the sample affected by Cerambycidae showed Chl values above the average Chl obtained for the sample of healthy holm oaks.

As regards the cork-oaks, the $\mathrm{T}$ statistic was significant when healthy trees were compared with trees affected by $C$. florentinus $(\mathrm{P}=0.001)$. In contrast, the test was no significant $(\mathrm{P}=0.982)$ if the average $\mathrm{Chl}$ content of undamaged trees was compared with the values of trees affected by species of the Cerambyx group (Table 2). 


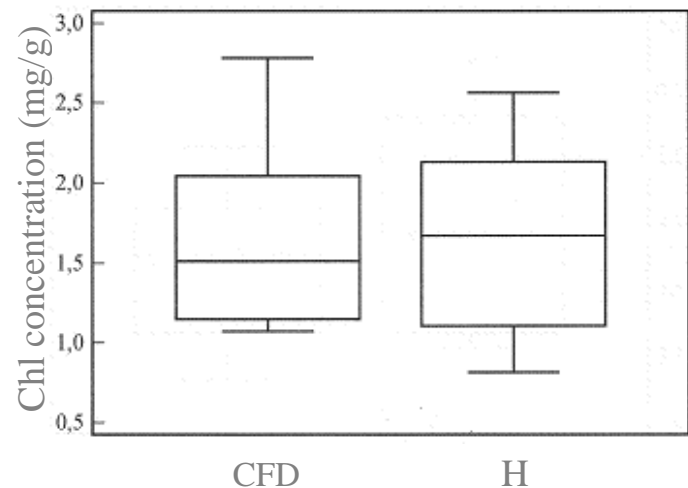

Figure 8. Graph of Chl content comparison between healthy holm oaks $(H)$ and those affected by Coraebus florentitus (CFD). Vertical bars indicate the minimum and maximum data values. The line in the box indicates the median value of the data. The upper and lower edges of the box indicate the $75^{\text {th }}$ and $25^{\text {th }}$ percentiles respectively

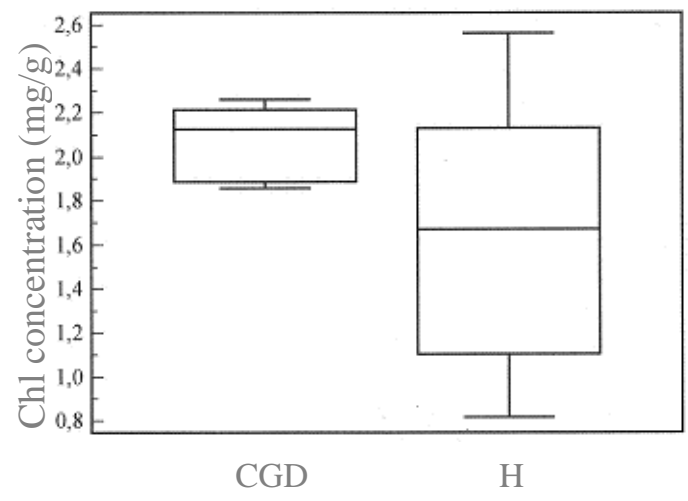

Figure 9. Graph of Chl content comparison between healthy holm oaks $(H)$ and those affected by Cerambyx group (CGD). The box plot interpretation as in Figure 8

\section{Relationships between damage by folivorous-insects and Chlorophyll content}

The average $\mathrm{Chl}$ content of trees damaged by leaf eating insects was compared with those of unharmed trees (see also Table 2). Three types of leaf damage caused by insects (bite, skeletonising and gall; see Methods section) were analyzed.

Summarising the information provide on Table 2, it should be mentioned that the statistic tests indicate no significant differences on average of Chl content when $Q$. ilex showing bites were compared with the sample of unharmed holm oaks $(\mathrm{P}=0.919)$. Nevertheless, the $\mathrm{T}$ statistic was significant when comparing healthy trees with trees affected by gall-formers $(\mathrm{P}=0.011)$. As only one holm oak was found exclusively displaying skeletonising damage; this data was not considered on the study.

Similar result was obtained when data from healthy specimens of $Q$. suber and those showing bites, skeletonising or gall damage are statically compared $(\mathrm{P}=0.333, \mathrm{P}=0.842$ and $\mathrm{P}=0.426$, respectively). The graphs comparing the data sets (Figure 10) showed a trend to have higher $\mathrm{Chl}$ content in trees damaged by biting insects.

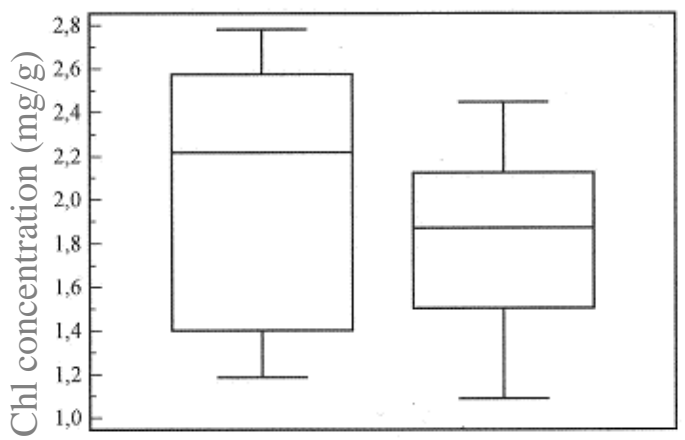

FD

$\mathrm{H}$

Figure 10. Graphs of Chl content comparison between healthy cork oaks $(H)$ and those showing damage caused by folivorous (FD). The box plot interpretation as in Figure 8 


\section{Discussion}

When assessing the incidence of harmful insects in a restored natural area, we perceived the need to have useful tools for diagnosing changes during the posterior monitoring. In consequence, we decided to explore different potential parameters susceptible to be applied for diagnosing stress by insect damage.

Bearing in mind previous studies, it may be assumed that $\mathrm{Chl}$ content may results a good short-term indicator of health in Quercus species because of its direct role in the photosynthetic process and because the leaf chlorophyll concentration responds, among others agents, to pest presence (Baldy et al., 1996 a and b). In addition, it is also assumed that chlorophyll content is strongly related to the photosynthetic functioning of plants and that this capacity varies in a range of environmental and phenological conditions (Barry et al., 2009). In order to avoid these shortcomings, the experiments in this research study were carried out in the middle of winter, just when variations in leaf chlorophyll content are considered to be minimal (Demarez et al., 1999).

Since it is also known that tree senescence is an integral age-related biological process intimately linked to Chl degradation (Iturraspe et al., 1995), and that perimeter is a suitable but indirect indicator of tree-age (Orozco, 1982), the corresponding analysis was performed to rule out the possibility that tree size could affect Chl concentration. Correlation between the perimeter of the group of unharmed trees and their respective Chl content revealed no significant differences for any of the studied species. Accordingly, a broader interpretation of our results could also rule out the possibility that tree age significantly affected $\mathrm{Chl}$ content in the studied Quercus.

Tests performed to compare average Chl content of unharmed holm oaks vs. damaged trees by $C$. florentinus or by species belonging to Cerambyx group did not reveal significant differences among any of these groups of trees.

Nevertheless, the additional information supplied in the box plots shows different trends: The holm oaks in the sample affected by Cerambycidae showed Chl values above the average $\mathrm{Chl}$ obtained for the sample of healthy holm oaks.

However the statistic was significant when healthy cork oaks were compared with those affected by $C$. florentinus. This result suggests that $Q$. suber seems to be highly sensitive to the effects of woodborers, although the shortage of data makes this result insufficiently reliable.

Accepted a positive relationship between photosynthetic activity and Chl content (Gratani et al., 1998), our observations contrast with those reported by Aldea et al. (2006) and Tang et al. (2006) that indicate a decrease in photosynthesis as response to herbivorous damage, but agree with those described by Bown et al. (2002), who interpreted the increase in $\mathrm{Chl}$ as a rapid local resistance mechanism to insect herbivory. According to these authors, insect presence on leaves stimulates the synthesis of certain substances (such as 4-aminobutyrate) and increases Chl concentration.

As regards skeletonising damage, no significant differences were observed in Chl concentration between unharmed and damaged trees. In this sense, both plant species behaved in the same way. In contrast, gall damage resulted in significant differences in average $\mathrm{Chl}$ content for $Q$. ilex. The presence of galls-forming insects also resulted in an increase in average Chl content. Contrarily, Aldea et al. (2006) mentioned the important effects of gall affectation with reduced photosynthetic efficiency over extended areas of leaves around visible damage.

Other question to be mentioned is the possible interaction between several harmful agents because when damage caused by one of them is intensified due to the presence of 
another, the response mechanisms may be more evident and may include changes in foliage quality and quantity. In this sense, Lower et al. (2003) indicated that change in foliage quality could influence a herbivore's ovipositing and feeding preferences, possibly resulting in a change in the intensity of the herbivore attack (Mizumachi et al., 2006). In addition, Compte and Caminero (1982) described a strong relationship between woodborer activity and high incidence of phytophagous (Lepidoptera caterpillar), so that the trees affected by any harmful pest are more vulnerable to suffer a second attack than healthy trees. This fact explains the difficulty during our fieldsampling to find trees only affected by a single type of damage, which was an important handicap for obtaining definitive results on this research. Survey of interactions among two or more types of damaging insects on Quercus Chl content is also necessary to validate the worth of this parameter to assess biotic stress of trees, but this issue will be addressed later.

In conclusion, the response of the level of Chl was highly variable in the different situation studied. Accordingly to the information available in literature, the observed changes do not respond to a constant pattern but vary depending on the plant species, the type of harmful agent that produces the stress.

Acknowledgements. We are grateful to the Agronomy Department (Vegetal Physiology staff) of the University of Cordoba, for their assistance in the chlorophyll extraction procedure. We would also like to thank ACUAES (Aguas de la Cuenca de España, S.A., Ministry of Agriculture, Food and Environment, Government of Spain) for financially supporting this research project.

\section{REFERENCES}

[1] Abbott, I., Heurck, P.V., Burbidge, T., Williams, M. (1993): Damage caused by insects and fungi to eucalypt foliage: spatial and temporal patterns in Mediterranean forest of Western Australia. - Forest Ecology and Management 58: 85-110.

[2] Aldea, M., Hamilton, J.G., Resti, J.P., Zangerl, A.R., Berenbaum, MR., DeLucia, E.H. (2005): Indirect effects of insect herbivory on leaf gas exchange in soybean. - Plant, Cell and Environment 28: 402-411.

[3] Aldea, M., Hamilton, J.G., Resti, J.P., Zangerl, A.R., Berenbaum, M.R., Frank, T.D., DeLucia, E.H. (2006): Comparison of photosynthetic damage from arthropod herbivory and pathogen infection in understory hardwood saplings. Oecologia 149: 221-232.

[4] Andicoberry, S., Arias, M.J., Benítez, M.A., Carrasco, A., Ceacero, C.J., Cordero, L., Díaz, M.C., Gimeno, D., González, E., Jiménez, M.E., Madueño, S., Ruiz, J.M., Sánchez, M.F., de la Hoz, F.M., Moreira, J.M., Giménez de Azcárate, F., Quijada, J., Gil, Y., Torres, E., Vela, J. (2007): El alcornoque y el corcho. - Ed. Consejería de Medio Ambiente, Junta de Andalucía, Sevilla.

[5] Baldy, R.W., Baldy, N.W., DeBenedictis, J.A., Granett, J., Osborn, B.P., Bledsoe, A., Bosch, D., Hlavka, C., Johnson, L., Weber, E. (1996 a): Assessment of leaf area, vine vigor, and grape yield and quality of Phylloxera-infested and non-infested grapevines in Napa County and their relationship to leaf reflectance, Chlrophyll, and mineral content. - Final report on NASA/Ames Research Center Joint Research Interchange NCC2-5062. 
[6] Baldy, R.W., DeBenedictis, J.A., Johnson, L., Weber, E., Baldy, M., Osborn, B., Burleigh, J. (1996 b): Leaf colour and vine size are related to yield in a phylloxera-infested vineyard. - Vitis 35(4): 201-205.

[7] Barry, K.M., Newnham, G.J., Stone, C. (2009): Estimation of chlorophyll content in Eucalyptus globulus foliage with the leaf reflectance model PROSPECT. - Agricultural and Forest Meteorology 149: 1209-1213.

[8] Bown, A.W., Hall, D.E., MacGregor, K.B. (2002): Insect footsteps leaves stimulate the accumulation of 4-aminobutyrate and can be visualized through increased chlorophyll fluorescence and superoxide production. - Plant Physiology 129: 1430-1434.

[9] Bussotti, F. (1994): Assessment of stress conditions in Quercus ilex L. leaves by O-J-I-P chlorophyll $a$ fluorescence analysis. - Plant Biosystems 138: 101-109.

[10] Cárdenas, A.M., Vargas, E., Gallardo, P., Pérez, S. (2008): Medidas Compensatorias del Proyecto de embalse de la Breña II. Estudio sobre coleópteros perforadores de Quercíneas. - Memoria Final, Universidad de Córdoba.

[11] Castro-Díez, P., Montserrat-Martí, G. (1998): Phenological pattern of fifteen Mediterraneam phanaerophytes from Quercus ilex communities of NE-Spain. Plant Ecology 139: 103-112.

[12] Colombo, S.J., Parker, W.C. (1999): Does Canadian forestry need physiology research. - Forestry Chronicle 75: 667-673.

[13] Compte, A., Caminero, M. (1982): Las comunidades de coleópteros xilófagos de las encinas de los alrededores de Madrid. - Graellsia 38: 201-217.

[14] Coulson, R.N., Witter, J.A. (1984): Forest Entomology: Ecology and Management. - Wiley-Interscience Publication.

[15] Demarez, V., Gastellu-Etchegorry, J.P., Mougin, E., Marty, G., Proisy, C., Dufrene, E., Le Dantec, V. (1999): Seasonal variation of leaf chlorophyll content a temperate forest. - International Journal of Remote Sensing 20(5): 879-894.

[16] Domínguez, F., Tejero, G. (1972): Plagas y enfermedades de las plantas cultivadas. - Dossat S.A., Madrid.

[17] Doyle, R.D., Grodowitz, M., Smart, R.M., Owens, C. (2002): Impact of herbivory by Hydrellia pakistanae (Diptera: Ephydridae) on growth and photosynthetic potential of Hydrilla verticillata. - Biological Control 24: 221229.

[18] El Omari, B., Fleck, I., Aranda, X., Moret, A., Nadal, M. (2001): Effect of fungal infection on leaf gas-exchange and chlorophyll fluorescence in Quercus ilex. - Annals of Forest Science 58: 165-174.

[19] Faeth, S.H. (1992): Interspecific and intraspecific via plant-responses to folivory an experimental field test. - Ecology 73: 1802-1813.

[20] Gallardo, P., Cárdenas, A.M., Gaju, M. (2010): Occurrence of Reticulitermes grassei (Isoptera: Rhinotermitidae) on cork oaks in the southern Iberian Peninsula: identification, description and incidence of the damage. Sociobiology 56: 675-687.

[21] Gratani, L., Moriconi, M. (1989): Seasonal changes in chlorophyll content and other characteristics of Quercus ilex L. leaves. - Photosynthetica 23: 89-93.

[22] Gratani, L., Pesoli, P., Crescente, M.F. (1998): Relationship between photosynthetic activity and chlorophyll content in an isolated Quercus ilex L. tree during the year. - Photosynthetica 35: 445-451. 
[23] Gratani, L., Bombelli, A. (2001): Differences in leaf traits among Mediterranean broad-leaved evergreen shrubs. - Annales Botanici Fennici 38: 15-24.

[24] Gu, M., Robbins, J.A., Rom, C.R., Hensley, D.L. (2008): Feeding damage of Japanese beetle (Col.: Scarabaeidae) on 16 field-grown birch (Betula L.) genotypes. - Journal of Applied Entomology 132: 425-429.

[25] Hochwender, C.G., Sork, V.L., Marquis, R.J. (2003): Fitness consequences of herbivory on Quercus alba. - American Midland Naturalist 150: 246-253.

[26] Howe, H.F. (1990): Survival and growth of juvenile Virola surinamensis in Panama: effects of herbivory and canopy closure. - Journal of Tropical Ecology 6: 259-280.

[27] Hunter, M.D. (2001): Effects of elevated atmospheric carbon dioxide on insectplant interactions. - Agricultural and Forest Entomology 3(3): 153-159.

[28] Iturraspe, J., Moyano, N., Frydman, B. (1995): A new 5-formylbilinone as the major chlorophyll a catabolite in tree senescent leaves. - Journal of Organic Chemistry 60: 6664-6665.

[29] Jiao, J., Goodwin, P., Grodzinski, B. (1999): Inhibition of photosynthesis and export in geranium grown at two $\mathrm{CO}_{2}$ levels and infected with Xanthomonas campestris pv. Pelargonii. - Plant, Cell and Environment 22: 15-25.

[30] Johnson, M.P., Hartman, J.R., McNiel, R.E., Fountain, W.M. (2001): Evaluation of dogwood and birch species and cultivars for resistance to key insect pest and diseases. - Journal of Environmental Horticulture 19: 73-78.

[31] Khadar, B., Prabhuraj, A., Srinivasa, M., Sreenivas, A.G., Naganagoud, A. (2014): Influence of elevated CO2 associated with chickpea on growth performance of gram caterpillar, Helicoverpa armigera (Hüb.). - Applied Ecology and Environmental Research 12(2): 345-353.

[32] Lichtenthaler, H.K., Wellburn, A.R. (1983): Determination of total carotenoid chlorophyll $\mathrm{a}$ and $\mathrm{b}$ of leaf extract in different solvents. - Biochemical Society Transactions 603: 591-592.

[33] Longonje, S.N., Rafaelli, D. (2014): Feeding ecology of Mangrobe crabs in cameroon. - Applied Ecology and Environmental Research 12(4): 959-973.

[34] Lower, S.S., Kirshenbaum, S., Orians, C.M. (2003): Preference and performance of willow-feeding leaf beetle: soil nutrient and flooding effects on host quality. Oecologia 136: 402-411.

[35] Marino, H. (2002): Respuestas ecofisiológicas de plantas en ecosistemas de zonas con clima mediterráneo y ambientes de alta montaña. - Revista Chilena de Historia Natural 75: 625-637.

[36] Mizumachi, E., Mori, A., Osawa, N., Akiyama, R., Tokuchi, N. (2006): Shoot development and extension of Quercus serrata saplings in response to insect damage and nutrient conditions. - Annals of Botany 98: 219-226.

[37] Montoya, J.M. (1989): Encinas y encinares. - Mundi Prensa, Madrid.

[38] Nagaraj, N., Reese, J.C., Kirkham, M.B., Kofoid, K. (2002): Relationship between chlorophyll loss and photosynthetic rate in Greenbug (Homoptera: Aphididae) damaged sorghum. - Journal of the Kansas Entomological Society 75: 101-109.

[39] Oliveira, G., Correia, O., Martins-Loucao, M.A., Catarino, F.M. (1994): Phenological and growth patterns of the Mediterranean oak Quercus suber L. Trees 9: 41-46.

[40] Orozco, M.F. (1982): Producción forestal. - Trillas, México. 
[41] Osmond, C.B., Berry, J.A., Balachandran, S., Buchenosmond, C., Daley, P.F., Hodgson, R.A.J. (1990): Potential consequences of virus infection for shade-sun acclimation in leaves. - Botanica Acta 103: 226-229.

[42] Palta, J.P. (1990): Leaf chlorophyll content. - Remote Sensing Reviews 5: 207213.

[43] Percival, G.C. (2004): Evaluation of physiological test as predictors of young tree establishment and growth. - Journal of Arboriculture 30(2): 80-92.

[44] Percival, G.C. (2005): Use of chlorophyll fluorescence to identify chemical and environmental stress in leaf tissue of three oak (Quercus) species. - Journal of Arboriculture 31(5): 215-227.

[45] Rivas-Martínez, S. (1974): La vegetación de la Clase Quercetea ilicis en España y Portugal. - Anales del Instituto Botánico Cavanilles 31(2): 205-259.

[46] Rodríguez de Cianzio, S., Fehr, W.R., Anderson, I.C. (1979): Genotypic evaluation for iron deficiency chlorosis in soybeans by visual scores and chlorophyll concentration. - Crop Science 19: 644-646.

[47] Romanyk, N., Cadahia, D. (1992): Plagas de insectos en las masas forestales españolas. - Colección técnica, MAPA, ICONA, Madrid.

[48] Sampson, P.H., Mohamed, G.H., Zarco-Tejada, P.J., Millar, J.R., Noland, T.L., Irving, D., Treitz, P.M., Colombo, S.J., Freementle, J. (2000): The bioindicators of forest condition Project: A physiological, remote sensing approach. - Forestry Chronicle 76(6): 941-952.

[49] Šesták, Z. (1966): Limitations for finding a linear relationship between chlorophyll content and photosynthetic activity. - Biologia Plantarum 8: 336346.

[50] Sampson, P.H., Mohamed, G.H., Zarco-Tejada, P.J., Millar, J.R., Noland, T.L., Irving, D., Treitz, P.M., Colombo, S.J., Freementle, J. (2000): The bioindicators of forest condition Project: A physiological, remote sensing approach. - Forestry Chronicle 76(6): 941-952.

[51] SPSS Inc. (2011): SPSS 20.0 for Windows Use Manual (version 20.0).

[52] Tang, J.Y., Zielinski, R.E., Zangerl, A.R., Crofts, A.R., Berembaum, M.R., DeLucia, E.H. (2006): The differential effects of herbivory by first and fourth instars of Trichoplusia $n i$ (Lepidoptera: Noctuidae) on photosynthesis in Arabidopsis thaliana. - Journal of Experimental Botany 57: 527-536.

[53] Welter, S.C. (1989): Arthropod impact on plant gas exchange. - In: Bernays, E.A. (ed.) Insect-plant Interactions, CRC Press, Boca Raton.

[54] Zar, J.H. (1984): Biostatistical analysis. - Prentice Hall, Inc. Englewood Cliffs, New Jersey.

[55] Zarco-Tejada, P.J., Miller, J.R., Mohammed, G.H., Noland, T.L., Sampson, P.H. (2002): Vegetation stress detection through chlorophyll $a+b$ estimation and fluorescence effects hyper spectral imagery. - Journal of Environmental Quality 31: 1433-1441.

[56] http://www.juntadeandalucia.es/agriculturaypesca/ifapa/ria/servlet 


\section{APPENDIX}

Appendix 1. Chl content $(\mathrm{mg} / \mathrm{g})$ of healthy Q. ilex and affected by one of the harmful agents analysed

\begin{tabular}{|c|c|c|c|c|c|}
\hline \multicolumn{6}{|c|}{ Chl content in $Q$. ilex } \\
\hline \multirow{2}{*}{$\begin{array}{c}\text { Harmless } \\
\text { trees }\end{array}$} & \multicolumn{4}{|c|}{ Trees damaged by: } & \multirow[b]{2}{*}{ Galls } \\
\hline & C. florentinus & Cerambyx sp. & Bites & Skeletonising & \\
\hline 2.229 & 1.826 & 1.218 & 1.357 & 0.979 & 2.710 \\
\hline 2.435 & 2.429 & 2.113 & 2.059 & & 1.605 \\
\hline 2.455 & 1.515 & 2.141 & 1.544 & & 1.909 \\
\hline 2.299 & 2.782 & 1.916 & 1.718 & & 2.416 \\
\hline 2.172 & 1.487 & 2.169 & & & 2.742 \\
\hline 2.039 & 1.993 & 2.261 & & & 2.195 \\
\hline 1.605 & 2.062 & 2.259 & & & 2.086 \\
\hline 1.162 & 1.142 & 1.857 & & & 1.785 \\
\hline 0.953 & 1.168 & 1.991 & & & 1.836 \\
\hline 1.354 & 1.089 & 1.993 & & & 1.544 \\
\hline 1.297 & 1.071 & & & & 1.718 \\
\hline 2.286 & & & & & 2.055 \\
\hline 2.563 & & & & & 2.075 \\
\hline 1.986 & & & & & 1.556 \\
\hline 1.952 & & & & & 2.088 \\
\hline 1.851 & & & & & \\
\hline 0.816 & & & & & \\
\hline 1.081 & & & & & \\
\hline 0.891 & & & & & \\
\hline 1.124 & & & & & \\
\hline 1.605 & & & & & \\
\hline 1.730 & & & & & \\
\hline 1.859 & & & & & \\
\hline 2.249 & & & & & \\
\hline 2.090 & & & & & \\
\hline 1.609 & & & & & \\
\hline 1.994 & & & & & \\
\hline 0.869 & & & & & \\
\hline 1.025 & & & & & \\
\hline 1.021 & & & & & \\
\hline 1.005 & & & & & \\
\hline 1.209 & & & & & \\
\hline
\end{tabular}


Appendix 2. Chl content ( $\mathrm{mg} / \mathrm{g}$ ) of healthy Q. suber and affected by one of the harmful agents analysed

\begin{tabular}{cccccc}
\hline \multicolumn{5}{c}{ Chl content in $\mathbf{Q}$. suber } \\
\hline Harmless & \multicolumn{5}{c}{ Trees damaged by: } \\
\cline { 2 - 6 } trees & C. florentinus & Cerambyx sp. & Bites & Skeletonising & Galls \\
\hline 2.123 & 3.239 & 1.653 & 2.382 & 1.429 & 2.382 \\
1.923 & 2.981 & 1.743 & 2.055 & 0.853 & 2.863 \\
2.057 & 2.900 & 1.513 & 2.590 & 1.208 & 1.913 \\
1.817 & & 2.528 & 2.783 & 1.177 & 1.904 \\
2.270 & & 1.660 & 2.561 & 2.382 & 1.177 \\
2.448 & & & 1.308 & 2.055 & \\
1.653 & & & 1.495 & 2.590 & \\
1.503 & & & 1.188 & 2.783 & \\
1.363 & & & 2.046 & 1.495 & \\
1.089 & & & 2.044 & 1.775 & \\
\hline
\end{tabular}

